\title{
I Mostra de Cinema sobre HIV/AIDS da Faculdade de Medicina da USP. A ampliação do conhecimento sobre uma epidemia por meio da discussão de filmes
}

\author{
First HIVIAIDS Cinema Festival from "Faculdade de Medicina \\ da Universidade de São Paulo". The enhancement of \\ knowledge about an epidemic through films discussion
}

\author{
Bianca Brunelli Eduardo', Gabriel Henrique Risso², Vera Paiva
}

\begin{abstract}
Eduardo BB, Risso GH, Paiva V. I Mostra de Cinema sobre HIV/AIDS da Faculdade de Medicina da USP. A ampliação do conhecimento sobre uma epidemia por meio da discussão de filmes/ First HIV/AIDS Cinema Festival from "Faculdade de Medicina da Universidade de São Paulo". The enhancement of knowledge about an epidemic through films discussion. Rev Med (São Paulo). 2012 jan.-mar.;91(1):16-8.

RESUMO: No acompanhamento às pessoas que vivem com HIV/AIDS, os profissionais de saúde nem sempre tratam da dimensão psicossocial implicada na infecção. O ensino médico requer o uso de estratégias que despertem o interesse e a crítica dos alunos para que seja prestado um atendimento mais integral ao indivíduo. Nos currículos de muitas escolas médicas brasileiras, há espaço para as chamadas Humanidades médicas, as quais visam à abordagem desses aspectos. A I Mostra de Cinema sobre HIV/AIDS da Faculdade de Medicina da USP utilizou longas-metragens seguidos por debates para abordar o processo histórico e social da resposta à infecção pelo HIV e os desafios interpostos.
\end{abstract}

DESCRITORES: HIV, Síndrome de imunodeficiência adquirida; Cinema como assunto; Cinema como assunto; Educação médica; Filmes.

\section{INTRODUÇÃO}

Trinta anos após os primeiros casos no Brasil, sabe-se que o atendimento às pessoas vivendo com a infecção pelo HIV/AIDS deve abordar mais que a fisiopatologia e a terapêutica. Hábitos de vida e também questões de ordem psicossocial atravessam necessariamente o cuidado do indivíduo. O panorama atual da infecção pelo HIV é muito diferente daquele observado nas décadas de 80 e 90. A terapia antirretroviral (TARV) inibe de forma eficaz a replicação viral, conferindo qualidade de vida e longevidade aos portadores. A epidemiologia recente dissociou a infecção dos chamados grupos

1. Acadêmica do terceiro ano do curso de Medicina da Faculdade de Medicina da Universidade de São Paulo.

2. Acadêmico do quarto ano do curso de Medicina da Faculdade de Medicina da Universidade de São Paulo.

3. Professora do Instituto de Psicologia da Universidade de São Paulo, Supervisora da Liga de Prevenção e Tratamento da Infecção por HIV/AIDS. 
de risco e passou a considerar a análise de risco associada à vulnerabilidade social e programática implicada na vulnerabilidade dos indivíduos de qualquer segmento social. Contudo, a força do plano cultural ainda mantém a associação da infecção com o estigma da doença implicado nas idéias de morte rápida, sofrimento, acusação e culpa. O profissional de saúde deve ser preparado para desmistificar tais concepções já no acolhimento ao indivíduo para a realização de exames pré-diagnósticos.

Os desafios no acompanhamento desses pacientes são inúmeros, como a adesão à TARV e o controle de seus efeitos colaterais, a prevenção de morbidades e a promoção de práticas sexuais seguras, além do manejo de preconceitos e medos arraigados tanto no soropositivo quanto no seu entorno social. Esses desafios somam-se ao estigma que influencia a relação com o profissional de saúde. Para que o paciente se sinta confortável para compartilhar suas questões íntimas, deve-se viabilizar uma conversa atenta e sem juízo de valores.

A base curricular das escolas médicas raramente capacita o estudante para lidar com a subjetividade do paciente e com seus desafios no plano psicossocial e, frequentemente, supervaloriza a técnica e o organicismo. Em virtude das discussões na área da saúde que objetivam uma atenção mais humanizada, umas das saídas para este problema seria a inclusão e a valorização das Humanidades médicas nos currículos da graduação. Para isso, novas metodologias e abordagens didáticas podem ser utilizadas para suscitar o interesse discente. Nessa perspectiva, foi escolhida a exibição de filmes, dada a atratividade e a fácil realização dessa iniciativa.

\section{OBJETIVO}

Apresentar e discutir questões que envolvem aspectos biopsicossociais e culturais da epidemia de HIV/AIDS por meio de recursos audiovisuais que ilustram o tema e da participação de profissionais que atuam na área.

\section{MÉTODO}

A I Mostra de Cinema sobre HIV/AIDS da Faculdade de Medicina da Universidade de São Paulo (FMUSP) foi organizada por acadêmicos do curso de Medicina e destinada principalmente aos estudantes e profissionais da área da saúde, e também aberta à população em geral. A divulgação foi realizada cerca de um mês antes do evento por meio de cartazes, panfletos, pôsteres, redes sociais, e-mail e blog. O material impresso foi distribuído na
Cidade Universitária (espaços internos e pontos de ônibus), na FMUSP, no Hospital das Clínicas, no Grupo de Incentivo à Vida e no Serviço de Extensão e Atendimento ao Paciente HIV/AIDS - HCFMUSP. O evento teve apoio financeiro da Comissão de Cultura e Extensão Universitária da FMUSP.

A mostra de cinema foi dividida em duas partes: apresentação de filme e discussão. Os filmes abordavam a evolução histórica da resposta à epidemia da AIDS e de suas repercussões sociais. Foram apresentados, na seguinte ordem, os longasmetragens: Milk (Gus Van Sant, 2008), And the Band Played On (Roger Spottiswoode, 1993), Philadelphia (Jonathan Demme, 1993) e Positivas (Susanna Lira, 2009). O filme Milk, embora não mencione HIV/AIDS, é importante para a compreensão da organização civil que antecedeu a mais forte resposta sociopolítica dada no início da epidemia. And the Band Played On, por sua vez, mostra os desafios sociais e políticos do estudo epidemiológico dos primeiros casos e as pesquisas laboratoriais que culminaram no isolamento do vírus. Já Philadelphia aborda os simbolismos da AIDS, o processo de estigmatização e as questões jurídicas e sociais associadas à discriminação dos soropositivos. O documentário nacional Positivas analisa a tendência epidemiológica de feminilização, heterossexualização e senilização da epidemia.

O evento ocorreu nos dias 13 de setembro, 20 de setembro, 04 de outubro e 11 de outubro de 2011, às 19h, em um anfiteatro da FMUSP. Após a exibição do filme, os espectadores participaram de discussões acompanhadas por especialistas de diversas áreas diretamente ligadas ao tema. A mesa foi composta por assistentes sociais, educadores, enfermeiros, médicos, psicólogos e representantes de ONGs. Foram distribuídos questionários para posterior avaliação do público e da atividade. As discussões de diferentes perspectivas e posições contribuíram para o aprofundamento dos diversos recortes temáticos.

\section{DISCUSSÃO}

O cinema acompanhado de debate mostrou-se um excelente método didático por ser abrangente, possibilitar maior empatia com os afetados pela epidemia e contextualizar diferentes cenários. Como é também uma forma de lazer, é uma atividade mais atrativa. A exibição de filmes permite diversas interpretações de acordo com o espectador e suas vivências. Essa pluralidade de visões enriquece o debate e, portanto, amplia a aprendizagem.

A sequência dos longas-metragens apresentados permitiu contar a história da epidemia com marcos e acontecimentos temporais baseados 
na sua evolução científica, política e sociocultural. Os debatedores enfatizaram o contexto brasileiro, a resposta nacional à AIDS, o tratamento oferecido pelo Sistema Único de Saúde e os seus desafios.

A discussão posterior ao filme deixou o público confortável para expor suas opiniões e dúvidas, ao possibilitar o compartilhamento de suas vivências e não pressupor conhecimentos prévios. Dessa maneira, houve intensa participação e dinamicidade no debate ao serem colocadas concepções e idéias sobre a infecção, comparando-a aos diversos significados que lhe foram atribuídos durante o processo histórico e que ainda perduram.

A presença de especialistas de várias inserções e de alunos de outras unidades auxiliou na construção de conhecimento junto aos espectadores que nortearam o debate de acordo com sua experiência profissional e pessoal, oriunda não só da prática relacionada à sua área de atuação, mas também da sua participação no processo histórico da epidemia como cidadãos.

\section{CONCLUSÃO}

A I Mostra de Cinema sobre HIV/AIDS da FMUSP, realizada por meio de exibição de filmes seguida de discussões, mostrou-se uma iniciativa produtiva de aprendizado à medida que possibilitou ampliar visões relacionadas à epidemia de HIV/AIDS. Além disso, o evento permitiu grande participação do público, resolução de dúvidas e compartilhamento de experiências. Portanto, essa abordagem, iniciada por alunos acompanhados por professores, deve ser considerada como uma possibilidade para o ensino médico e deve ser levada em conta no processo de transmissão e produção de conhecimento relacionado à dimensão política, cultural e intersubjetiva inerentes ao processo saúde-doença.

\section{REFERÊNCIAS}

1. Tapajós R. Introducing the arts into medical curricula, Interface Comunic Saúde Educ. 2002;6 (10):27-36.

2. Ayres JRCM. Educational practices and the prevention of HIV/Aids: lessons learned and current challenges. Interface Comunic Saúde Educ. 2002;6(11):11-24. 